Louisiana State University

LSU Digital Commons

Faculty Publications

Department of Biological Sciences

8-1-2007

\title{
Field studies of anoxic conditions in the Baltic Sea during the cruise of R/V Professor Albrecht Penck in July 2006
}

\author{
G. Jost \\ The Leibniz Institute for Baltic Sea Research \\ B. Clement \\ Oregon Health \& Science University \\ S. V. Pakhomova \\ P.P.Shirshov Institute of Oceanology, Russian Academy of Sciences \\ E. V. Yakushev \\ P.P.Shirshov Institute of Oceanology, Russian Academy of Sciences
}

Follow this and additional works at: https://digitalcommons.Isu.edu/biosci_pubs

\section{Recommended Citation}

Jost, G., Clement, B., Pakhomova, S., \& Yakushev, E. (2007). Field studies of anoxic conditions in the Baltic Sea during the cruise of R/V Professor Albrecht Penck in July 2006. Oceanology, 47 (4), 590-593.

https://doi.org/10.1134/S0001437007040170

This Article is brought to you for free and open access by the Department of Biological Sciences at LSU Digital Commons. It has been accepted for inclusion in Faculty Publications by an authorized administrator of LSU Digital Commons. For more information, please contact ir@lsu.edu. 


\title{
Field Studies of Anoxic Conditions in the Baltic Sea during the Cruise of R/V Professor Albrecht Penck in July 2006
}

\author{
G. Jost ${ }^{a}$, B. Clement ${ }^{b}$, S. V. Pakhomova ${ }^{c}$, and E. V. Yakushev ${ }^{d}$ \\ ${ }^{a}$ Baltic Sea Research Institute, Warnemuende, Germany \\ ${ }^{b}$ Oregon Health and Science University, Portland, USA \\ ${ }^{c}$ Shirshov Institute of Oceanology, Russian Academy of Sciences, Moscow, Russia \\ ${ }^{d}$ Southern Branch, Shirshov Institute of Oceanology, Russian Academy of Sciences, Gelendzhik, Russia \\ e-mail: e-yakushev@yahoo.com \\ Received February 13, 2007
}

DOI: $10.1134 / \mathrm{S} 0001437007040170$

The Baltic Sea Research Institute (Warnemuende, tists included, conducted studies on board the R/V ProGermany) carries out regular investigations of the $\mathrm{H}_{2} \mathrm{~S}$ - fessor Albrecht Penck. The vertical hydrophysical, containing deep waters of the Baltic Sea. In July of hydrochemical, and microbiological structures of the 2006, an international scientific team, Russian scien- Gotland (station TF0271) and Landsort (station

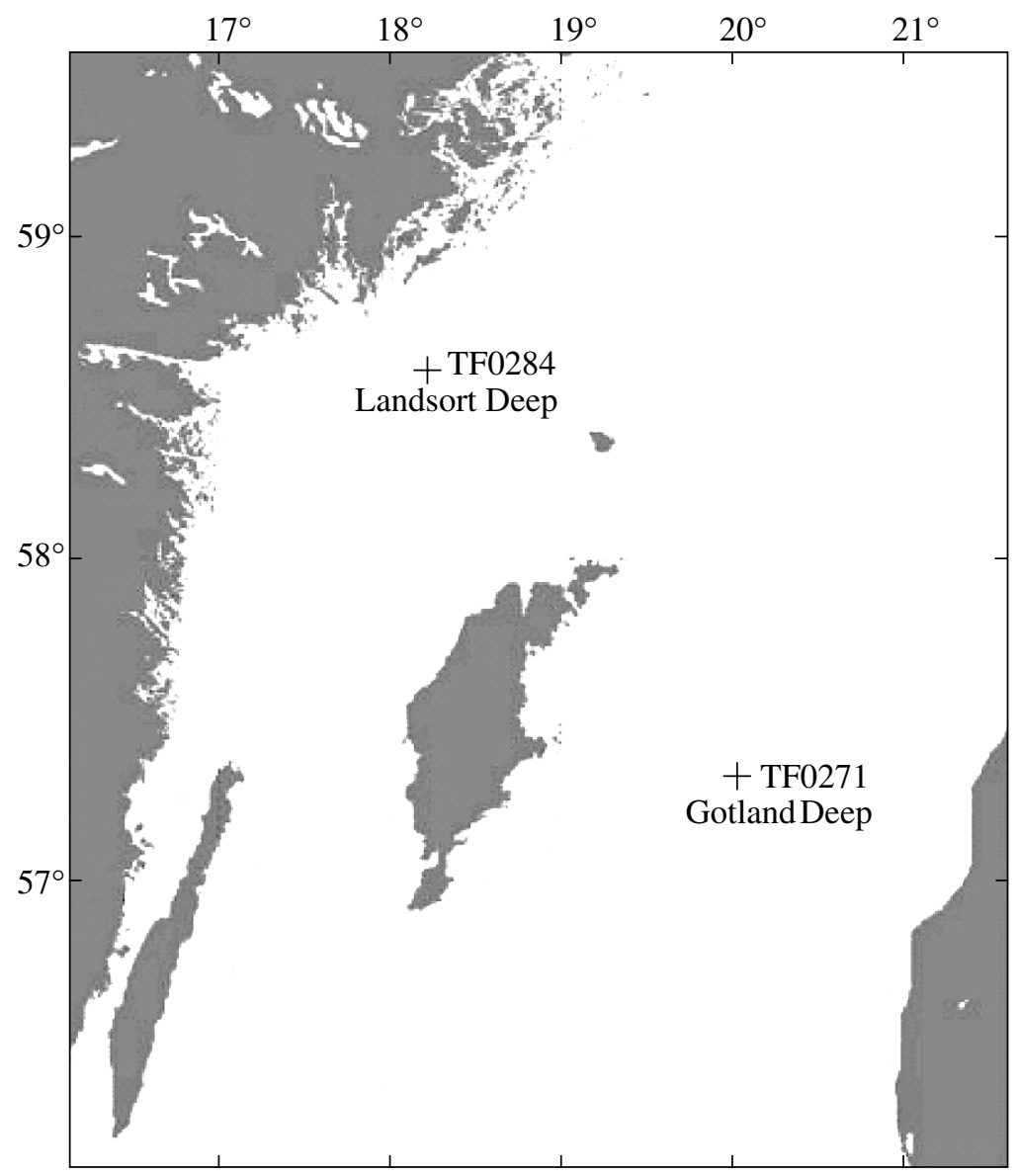

Fig. 1. Scheme of the studies during the cruise of R/V Albrecht Penck in July 2006. 


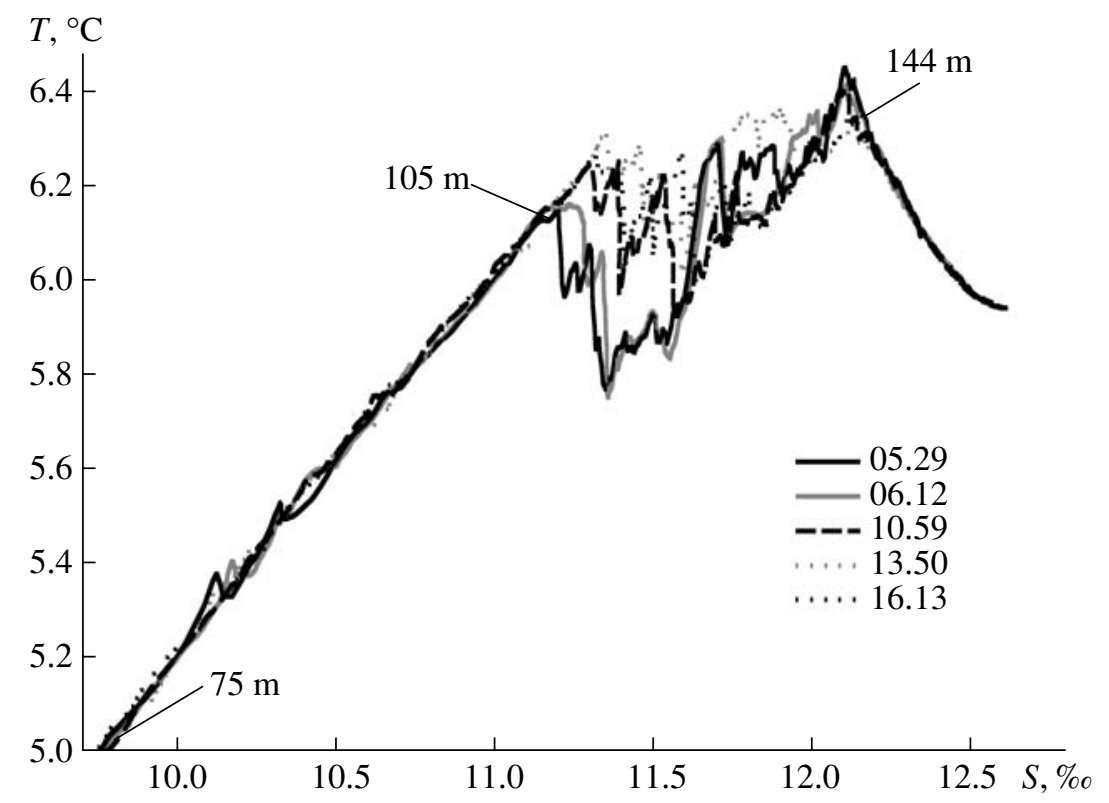

Fig. 2. $T, S$ curves based on the results of five CTD profiles at station 271 (at 05:29; 06:12; 10:59; 13:50, and 16:13 GMT) on July 9, 2006.

TF0284) deeps were studied during this cruise (Fig. 1). Its purpose was to investigate the influence of the intrusions that are formed near the chemocline and clarify the fine hydrochemical structure of the near-bottom waters.

The water was sampled using a Rosette complex equipped with a Sea Bird-19 hydrophysical probe with sensors of the pressure, temperature, electrical conductivity, turbidity, fluorescence, and oxygen, as well as with 13 Free-Flo (5 1) bottle samplers. The contents of dissolved oxygen (Winkler titration), phosphates, silicates, nitrates, nitrites, ammonium, and hydrogen sulfide (photometrically) were determined in line with the traditional techniques [2,3]. Samples collected for determining the dissolved metals were filtered through Nuclepore filters with a mesh size of $0.45 \mu \mathrm{m}$ immediately after sampling. Fe and Mn were determined photometrically using ferrozine and formaldoxime in line with [3]. In addition, samples for determining the alkalinity and methane (at station TF0284 in the Landsort Basin) and suspended metal forms were taken.

The Landsort chemocline was out of the influence of intrusions during the cruise, which made it possible to observe the undisturbed vertical chemical structure, which appeared to be similar with that typical of the Black Sea. The nitrate maximum was located near the lower boundary of the oxycline, while the nitrite maximum corresponded to the layer marked by a decline in the deep ammonium and dissolved $\mathrm{Mn}$, the disappearance of nitrates, and a sharp decrease in the phosphate content. The Winkler method (titration using an automatic Titrino burette with proprietary software) failed to estimate oxygen in the samples with detectable contents of hydrogen sulfide $(0.3 \mu \mathrm{mol} / \mathrm{l})$.

In the Gotland chemocline, the hydrochemical structure of the redox layer was under the influence of intrusions during practically the entire observation period. These intrusions were responsible for both the deepening of the redoxcline relative to its typical position and the instability in the layer from 105 to $145 \mathrm{~m}$ as is evident from the variations in the $T$-S curves characterizing a single day (Fig. 2). Figure 3 a demonstrates the parameters of the fine hydrochemical structure measured during the same day. It is seen that these intrusions with elevated oxygen contents resulted in an extreme temporal variability of the distribution profiles of the hydrochemical parameters. The most unusual structure was observed at station 0003F02 (Fig. 3b), where it was characterized by a narrow phosphate minimum immediately beneath the hydrogen sulfide boundary and a maximum under the latter. The distribution of the dissolved (bivalent) manganese appeared to be similar: its distinct maximum coincided with that of phosphates. This may indicate that the distribution of these parameters is controlled by the same mechanism, namely, by the formation of phosphate-bearing complexes with oxidized dissolved trivalent manganese. The measured content of trivalent manganese was comparable with the detection limit of the method (approximately $1 \mu \mathrm{M}$ ) and its role remains unclear so far. During the cruise, we also conducted an experiment to study the distribution of manganese in different size fractions-suspended $(>0.2 \mu \mathrm{m})$, colloid (from 0.2 to $0.02 \mu \mathrm{m})$, and dissolved $(<0.02 \mu \mathrm{m})$. The preliminary 


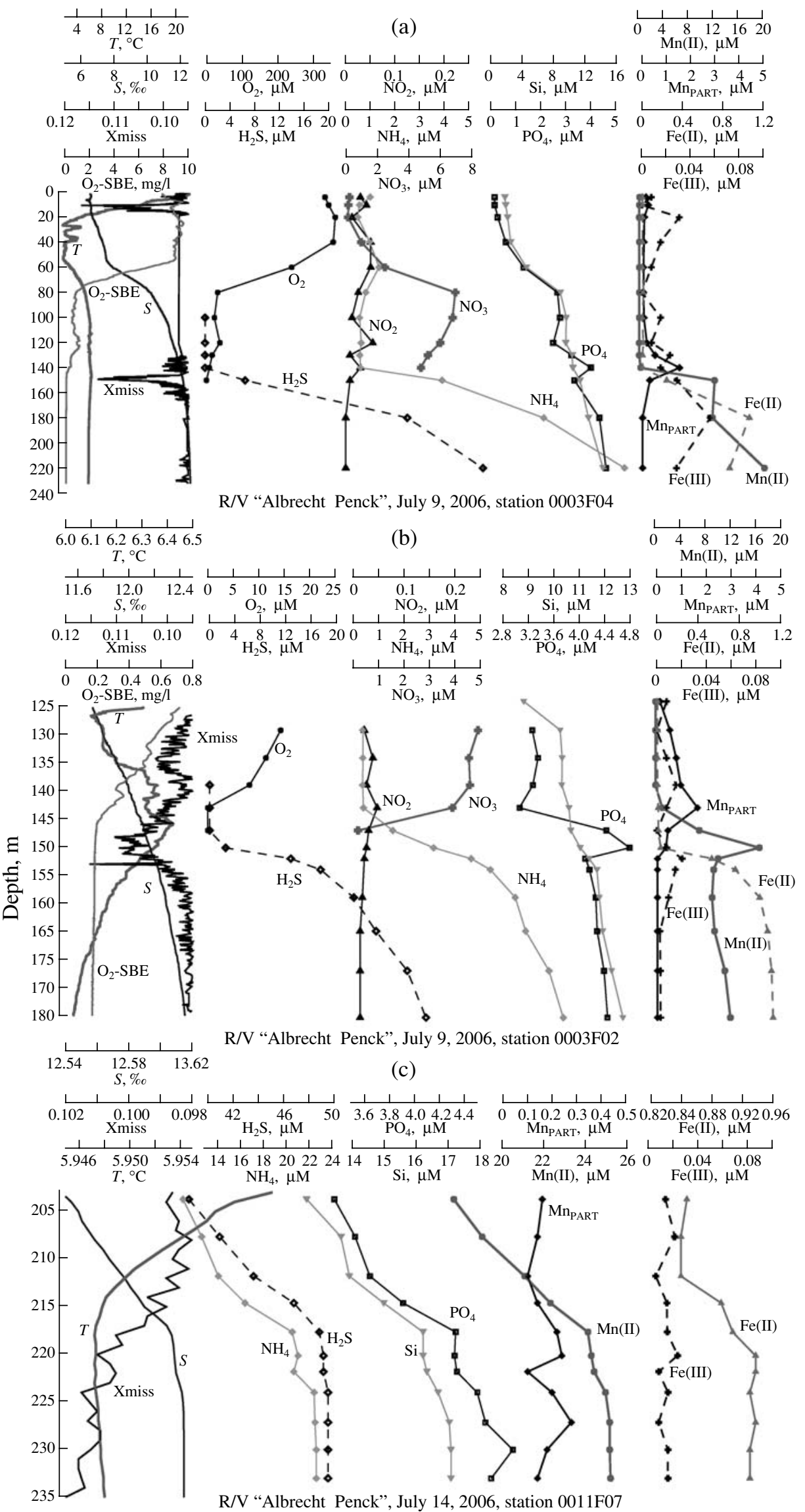


Fig. 3. Vertical distributions of the temperature $(T)$, salinity $(S)$, turbidity $(X m i s s)$, dissolved oxygen according to the $\mathrm{O}_{2}$-SBE sensor, dissolved oxygen according to titration $\left(\mathrm{O}_{2}\right)$, hydrogen sulfide $\left(\mathrm{H}_{2} \mathrm{~S}\right)$, phosphates $\left(\mathrm{PO}_{4}\right)$, silicates $(\mathrm{Si})$, nitrates $\left.(\mathrm{NO})_{3}\right)$, nitrites $\left(\mathrm{NO}_{2}\right)$, ammonium $\left(\mathrm{NH}_{4}\right)$, dissolved manganese $(\mathrm{Mn}(\mathrm{II})$ ), particulate manganese (MnPART), reduced iron (Fe (II)), and oxidized iron (Fe(III) at stations (a) 0003F04, (b) 0003F02, and (c) 0011007.

results of the experiment show that colloid manganese is missing (below the detection limit of $100 \mathrm{nM}$ ).

Figure $3 \mathrm{c}$ demonstrates the data on the near-bottom layer of the Gotland basin studied with a sampling distance of every $2-3 \mathrm{~m}$. They depict the 20 -m-thick nearbottom mixed layer (NBML), which is characterized by a slight (approximately $0.002^{\circ} \mathrm{C}$ ) temperature increase and uniform distributions of salinity, hydrogen sulfide, ammonium, phosphates, silicates, dissolved Fe, and dissolved Mn. Their gradients are substantially lower than those in the upper water layers. A step with a sharp gradient increase in all the parameters is recorded at a depth of $215 \mathrm{~m}$ at the NBML boundary. A similar distribution of the chemical parameters is characteristic of the Black Sea basin [1], although the near-bottom layer in the latter is thicker $(300-500 \mathrm{~m})$. A small step in the gradient changes in the Baltic Sea NBML may be defined at a depth of $223 \mathrm{~m}$. It is conceivable that the latter is related to an intrusion of the waters with elevated salinity.

\section{REFERENCES}

1. I. I. Volkov, A. Yu. Skirta, P. N. Makkaveev, et al., "On the Hydrophysical and Hydrochemical Homogeneity of the Abyssal Waters of the Black Sea," in Multidisciplinary Studies in the Northeastern Part the Black Sea, Ed. by A. G. Zatsepin and M. V. Flint (Nauka, Moscow, 2002), pp. 161-169 [in Russian].

2. Modern Methods for Hydrochemical Studies in the Oceans, Ed. by O. K. Bordovskii and A. M. Chernyakova (IO RAN, Moscow, 1992) [in Russian].

3. Methods of Seawater Analysis, Ed. by K. Grashoff, K. Kremling, and M. Ehrhard, 2nd ed. (WILEY-VCH, Weinheim-NewYork, 1999). 